\title{
Production and Partial Characterization of an Alkaline Xylanase from a Novel Fungus Cladosporium oxysporum
}

\author{
Guo-Qiang Guan, ${ }^{1}$ Peng-Xiang Zhao, ${ }^{2,3}$ Jin Zhao, ${ }^{3}$ Mei-Juan Wang, ${ }^{1}$ Shu-Hao Huo, \\ Feng-Jie Cui, ${ }^{1}$ and Jian-Xin Jiang ${ }^{2,3}$ \\ ${ }^{1}$ School of Food and Biological Engineering, Jiangsu University, Zhenjiang 212013, China \\ ${ }^{2}$ Department of Chemical Engineering, Beijing Forestry University, Beijing 100083, China \\ ${ }^{3}$ Beijing Biomass Energy Technology Center, State Grid Energy Conservation Service Ltd., Beijing 100053, China \\ Correspondence should be addressed to Feng-Jie Cui; fengjiecui@163.com and Jian-Xin Jiang; jiangjianxin@163.com
}

Received 9 December 2015; Revised 16 February 2016; Accepted 2 March 2016

Academic Editor: Anne Hamburger

Copyright (C) 2016 Guo-Qiang Guan et al. This is an open access article distributed under the Creative Commons Attribution License, which permits unrestricted use, distribution, and reproduction in any medium, provided the original work is properly cited.

A new fungus Cladosporium oxysporum GQ-3 producing extracellular xylanase was isolated from decaying agricultural waste and identified based on the morphology and comparison of internal transcribed spacer (ITS) rDNA gene sequence. C. oxysporum produced maximum xylanase activity of $55.92 \mathrm{U} / \mathrm{mL}$ with wheat bran as a substrate and $\mathrm{NH}_{4} \mathrm{Cl}$ as a nitrogen source. $\mathrm{Mg}^{2+}$ improved C. oxysporum xylanase production. Partially purified xylanase exhibited maximum activity at $50^{\circ} \mathrm{C}$ and $\mathrm{pH} 8.0$, respectively, and showed the stable activity after 2 -h treatment in $\mathrm{pH} 7.0-8.5$ or below $55^{\circ} \mathrm{C} . \mathrm{Mg}^{2+}$ enhanced the xylanase activity by $2 \%$ while $\mathrm{Cu}{ }^{2+}$ had the highest inhibition ratio of 57.9\%. Furthermore, C. oxysporum xylanase was resistant to most of tested neutral and alkaline proteases. Our findings indicated that Cladosporium oxysporum GQ-3 was a novel xylanase producer, which could be used in the textile processes or paper/feed industries.

\section{Introduction}

Xylan is wide variety of highly complex polysaccharides mainly composed of xylose units in renewable lignocellulosic biomass resources such as cereal straws, sugarcane bagasse, corn stover, and wood sawdust [1]. Generally, xylan must be firstly hydrolyzed to liberate the fermentable xylose for complete utilization of theses lignocellulosic materials [2]. Microbial or enzymatic hydrolysis of xylan requires the integrative action of multiple enzyme complexes including xylanase (1,4- $\beta$-D-xylan xylanohydrolase, EC 3.2.1.8), $\beta$ xylosidase (EC 3.2.1.37), $\alpha$-L-arabinofuranosidases, and $\alpha$ glucosidases [3]. Among them, xylanases have the significant merits of high specificity, mild reaction conditions, and negligible substances loss/side products generation $[4,5]$ and have been commercially applied in the paper, food additives, feed, and fruit juices industries [6-9].

Xylanases are produced by bacteria [10], fungi [11], actinomycetes [12], and engineered yeasts [13]. Of these, filamentous fungi such as Aspergillus, Penicillium, and
Trichoderma have been proved to have a significant capability of secreting a wide range of xylanases. Our previous work also found that the screened fungi Penicillium sp. WX-Z1, Penicillium oxalicum ZH-19, and Aspergillus sp. Zh-26 could produce xylanases with the highest activity of $46.50 \mathrm{U} / \mathrm{mL}$, $80.23 \mathrm{U} / \mathrm{mL}$, and $47.30 \mathrm{U} / \mathrm{mL}$ under their optimized fermentation conditions, respectively $[14,15]$. For a more efficient degradation of xylan, it is still an ongoing interest to find new xylanases with excellent activity and stability in various reaction conditions. Hence, the present study aimed to isolate the potential xylanase secreting strains, identify the strains using morphology and internal transcribed spacer (ITS) rDNA gene sequence analysis, determine culture conditions for maximum xylanase production, and characterize partially purified xylanase.

\section{Materials and Methods}

2.1. Isolation of Xylanase Secreting Microorganisms. For screening xylanase secreting strains, about $1.0 \mathrm{~g}$ of decaying 
wheat straw, collected in the Maoshan Town, Zhenjiang City, Jiangsu Province, was added to the screening media (g/L): $\mathrm{KNO}_{3} 3.0, \mathrm{~K}_{2} \mathrm{HPO}_{4} 0.5, \mathrm{MgSO}_{4} \cdot 7 \mathrm{H}_{2} \mathrm{O} 0.5$, and $\mathrm{KCl}$ 0.5 . After being cultured at $30^{\circ} \mathrm{C}$ for $2-\mathrm{d}$, the isolate was inoculated on Petri dishes containing $(\mathrm{g} / \mathrm{L})$ wheat bran 5.0, $\mathrm{KH}_{2} \mathrm{PO}_{4} 0.5$, and agar 10.0 , at $30^{\circ} \mathrm{C}$ for $6-\mathrm{d}$. The developed colonies were seeded to the fermentation media consisting of $(\mathrm{g} / \mathrm{L})$ wheat bran $5.0, \mathrm{NH}_{4} \mathrm{Cl} 10.0, \mathrm{KH}_{2} \mathrm{PO}_{4} 1.0, \mathrm{NaCl}$ 1.0, $\mathrm{MgSO}_{4} \cdot 7 \mathrm{H}_{2} \mathrm{O} 1.0, \mathrm{CaCl}_{2} \cdot 2 \mathrm{H}_{2} \mathrm{O} 0.5$, and yeast extract 1.0, for determining xylanase production. The chemicals of reagent grade for preparing media or determining xylanase activity were obtained from Sinopharm Chemical Reagent Co., Ltd. (Shanghai, China). One fungal isolate with highest xylanolytic activity was designated as GQ-3 and ultimately chosen for further study.

2.2. Phylogenetic Analysis of Fungal Isolate. Genomic DNA of fungal isolate was extracted from fresh cultures and used as template for PCR amplification using a method described previously [16]. The ITS1-5.8S-ITS2 rDNA region of the fungi was amplified by PCR using primer set pITS1 ( $5^{\prime}$-TCCGTAGGTGAACCTGCCG- $3^{\prime}$ ) and pITS4 (5'-TCCTCCGCTTATTGATATGC- $\left.3^{\prime}\right)$. PCR amplification conditions were as follows: predenaturing at $95^{\circ} \mathrm{C}$ for $5 \mathrm{~min}, 30$ cycles of denaturation at $95^{\circ} \mathrm{C}$ for $1 \mathrm{~min}$; annealing at $55^{\circ} \mathrm{C}$ for $1 \mathrm{~min}$; and prolonging at $72^{\circ} \mathrm{C}$ for $1 \mathrm{~min}$, before the extension at $72^{\circ} \mathrm{C}$ for $10 \mathrm{~min}$ and final cooling to $4^{\circ} \mathrm{C}$. Electrophoresis was used to examine PCR products in a $0.8 \%(\mathrm{w} / \mathrm{v})$ agarose gel in $1 \times$ TAE buffer (0.4 M Tris, $50 \mathrm{mM} \mathrm{NaOAc,} 10 \mathrm{mM}$ EDTA, $\mathrm{pH}$ 7.8). The amplified DNA fragment was cloned into the pMD18-T vector (Takara, Japan) and its nucleotide sequence was determined using an Applied Biosystems 377B automatic DNA sequencer (Applied Biosystems, Foster, CA, USA). The resulting sequences obtained were queried against the GenBank database using Basic Local Alignment Search Tool (BLAST) program. The neighbor-joining (NJ) method and maximum parsimony (MP) method from the PHYLIP suit program were used for constructing the phylogenetic tree. Bootstrap analysis was used to evaluate the tree topology of the NJ data by performing 1,000 resamplings and marking the branching points. The evolutionary distance matrix was estimated according to Kimura's two-parameter model.

2.3. Culture Conditions. The culture seed was prepared by growing fungal cells on PDA slopes at $30^{\circ} \mathrm{C}$ for $6 \mathrm{~d}$ and adjusted the cells concentration to $10^{6}$ spores $/ \mathrm{mL}$ with sterile distilled water.

The basal medium for one-factor-at-a-time experiments was composed of $(\mathrm{g} / \mathrm{L})$ wheat bran 5.0, $\mathrm{KH}_{2} \mathrm{PO}_{4}$ 1.0, $\mathrm{MgSO}_{4} \cdot 7 \mathrm{H}_{2} \mathrm{O} 1.0, \mathrm{CaCl}_{2} \cdot 2 \mathrm{H}_{2} \mathrm{O} 0.3$, and yeast extract 1.0 . Effect of carbon sources and nitrogen sources on xylanase production was evaluated by substituting glucose or yeast extract in the basal medium, respectively. Four fermentation temperatures from $25^{\circ} \mathrm{C}$ to $42^{\circ} \mathrm{C}$, and 7 initial pHs from 3.0 to 9.0 were used for selecting the optimal temperature and initial $\mathrm{pH}$ with the media containing wheat bran $(1.0 \%$, w/v). Fermentation was conducted at $30^{\circ} \mathrm{C}$ on a rotary shaker $(150 \mathrm{rpm})$ for $5 \mathrm{~d}$ if not further specified. The sample was withdrawn at regular intervals and centrifuged at 14,000 rpm $\left(4^{\circ} \mathrm{C}\right)$ for $10 \mathrm{~min}$ to collect supernatant as the crude enzyme for determining xylanase activity.

2.4. Xylanase Activity Assays. The xylanase activity was expressed by release of reducing sugars from oat spelt xylan $(1 \%, w / v)$ using the dinitrosalicylic acid method [17]. Reaction mixture contained $2 \mathrm{~mL}$ of a solution of $1 \%$ oat spelt xylan in citrate buffer $50 \mathrm{mM}, \mathrm{pH} 5.0$, and $1 \mathrm{~mL}$ of the diluted enzyme. The mixture reacted at $50^{\circ} \mathrm{C}$ for $30 \mathrm{~min}$. One unit of xylanase was defined as the amount of enzyme required to released $1 \mu \mathrm{mol}$ of xylose from xylan in $1 \mathrm{~min}$.

Protein concentration was determined using a Bradford Protein Assay Kit (Sangon Biotech, Shanghai, China) with bovine serum albumin as a standard protein. Specific activity was expressed as the number of xylanase units per milligram of enzyme protein.

2.5. Preparation of Partial Purified Xylanases. The culture supernatant was concentrated 10 -fold by ultrafiltration membrane with molecular weight cutoff (MWCO) of $10 \mathrm{kDa}$ (Millipore, MA, USA) and precipitated with $40 \%$ saturation ammonium sulfate. The protein precipitate was dissolved in potassium phosphate buffer solution (PBS), loaded onto a DEAE-Sepharose Fast Flow column $(1.2 \mathrm{~cm} \times 60 \mathrm{~cm})(\mathrm{GE}$ Healthcare, MA, USA), and step-wisely washed with a discontinuous gradient of PBS, PBS containing $0.3 \mathrm{~mol} / \mathrm{L} \mathrm{NaCl}$, and PBS containing $0.5 \mathrm{~mol} / \mathrm{L} \mathrm{NaCl}$. The elution fractions having xylanolytic activity were collected and lyophilized for biochemical characterization.

2.6. Effect of $p H$ and Temperature on Partially Purified Xylanase Activity and Stability. The enzymes were mixed with buffers with varying $\mathrm{pH}$ at $1: 10(\mathrm{v} / \mathrm{v})$ ratio and incubated for $60 \mathrm{~min}$ to identify the optimal $\mathrm{pH}$ and $\mathrm{pH}$ stability. The buffers used were as follows: $0.2 \mathrm{M}$ acetate buffer ( $\mathrm{pH} 3.0-$ 5.0), 0.2 M phosphate buffer ( $\mathrm{pH} 6.0-7.5)$, and 0.2 M Tris$\mathrm{HCl}$ buffer (pH 7.5-9.0).

The optimum catalytic temperature of partially purified xylanase was selected by determining the enzyme activity in the range of $30-70^{\circ} \mathrm{C}$. The temperature stability was determined by measuring the residual xylanolytic activity after being treated with temperatures from 40 to $70^{\circ} \mathrm{C}$ for 0.0 , $0.5,1.0,2.0$, and $3.0 \mathrm{~h}$.

2.7. Effect of Metal Ions on Partially Purified Xylanase Activity. Effect of metal ions on xylanase activity was evaluated by incubating reaction mixtures containing $1.0 \%$ oat spelt xylan with $\mathrm{K}^{+}, \mathrm{Mn}^{2+}, \mathrm{Na}^{+}, \mathrm{Mg}^{2+}, \mathrm{Fe}^{2+}, \mathrm{Cu}^{2+}, \mathrm{Li}^{+}, \mathrm{Co}^{2+}, \mathrm{Hg}^{2+}$, and $\mathrm{Zn}^{2+}$ at the concentrations of $1.0 \mathrm{mM}$. Inhibition/activation degree of xylanase activity was expressed as percentage of a control sample incubated in absence of any additive.

2.8. Effect of Proteases on Xylanase Activity. Resistance of partially purified xylanase to proteases was tested by adding neutral and alkaline proteases including proteinase $\mathrm{K}$ (from Tritirachium album), pepsin, trypsin, and collagenase (from Clostridium histolyticum) with unit of $10.0 \mu \mathrm{g} / \mathrm{mL}$. The residual xylanolytic activity was measured after 3 -h preincubation at $37^{\circ} \mathrm{C}$. The reaction mixture without proteases was used as control. 


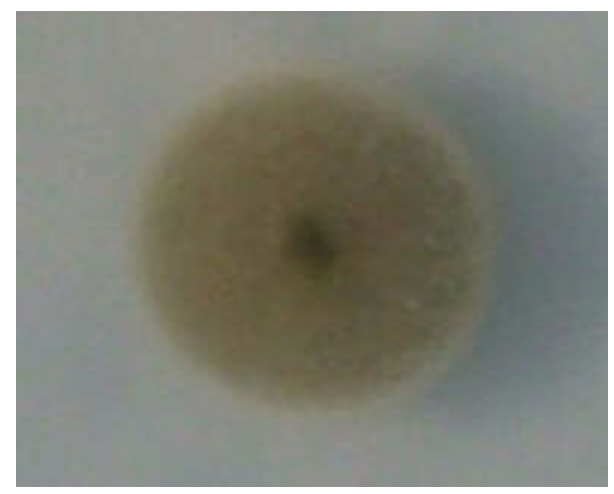

FIgURE 1: Colony morphology of Cladosporium oxysporum after growth at $30^{\circ} \mathrm{C}$ for 7 days on potato dextrose agar (PDA).

2.9. Statistical Analysis. Each experiment was repeated three times using duplicate samples. The results were expressed as means \pm standard deviations. Statistical comparisons were made by one-way analysis of variance (ANOVA), followed by Duncan's multiple-comparison test. Differences were considered significant when the $P$ values were $<0.05$.

\section{Results and Discussion}

3.1. Identification of Strain Cladosporium oxysporum GQ-3. The colony morphology of fungal isolate GQ-3 after 7-d cultivation on potato dextrose agar (PDA) at $30^{\circ} \mathrm{C}$ was shown in Figure 1. Phylogenetic analysis also confirmed the maximum closeness of the fungal isolate with Cladosporium oxysporum (Figure 2). The nucleotide sequence in internal transcribing spacer (ITS) region was also compared with blast (NCBI) and showed $98.5 \%$ similarity with that of Cladosporium oxysporum ATCC 76499. Hence, the fungal isolate was identified as a strain of $C$. oxysporum and named C. oxysporum GQ3 based on the morphology and comparison of ITS rDNA gene sequence. The sequence has been deposited in NCBI GenBank database with accession number: DQ912837. Previous studies revealed that C. oxysporum had the pathogenicity causing death and hyphal growth of P. citri, Pseudococcus longispinus (T.T.), Coccus aethiopicus De Lotto, and Trioza erytreae (del Guercio) [18] and produced the antiproliferative taxol against human pathogenic bacteria and human colon cancer cell line HCT 15 [19]. To the best of our knowledge, the screened C. oxysporum GQ-3 was the new record to produce xylanase.

3.2. Effect of Carbon Source on Xylanase Production. From Table 1, starch at the concentration of $1.0 \%(\mathrm{w} / \mathrm{v})$ yielded the low xylanase activity of $1.95 \pm 0.46 \mathrm{U} / \mathrm{mL}$ while wheat bran led to the maximum xylanase activity of $52.94 \pm 3.17 \mathrm{U} / \mathrm{mL}$, followed by oat xylan and corn cob, which indicated that the substrates containing xylan could induce xylanase production by Cladosporium oxysporum. Generally, the lignocellulosic material, such as barley husk, corn cobs, hay, wheat bran, or straw, had the advantage of pure xylan or xylose due to the low cost to produce xylanase in a larger scale. Wheat bran is rich in carbohydrates (including glucan $10.5 \%$,
TABLE 1: Effect of carbon source on xylanase production by $C$. oxysporum GQ-3 at $30^{\circ} \mathrm{C}$ under submerged fermentation for $5 \mathrm{~d}$.

\begin{tabular}{lc}
\hline Carbon source $(\mathrm{w} / \mathrm{v})$ & Xylanase activity $(\mathrm{U} / \mathrm{mL})^{*}$ \\
\hline $0.5 \%$ wheat bran & $30.77 \pm 1.25$ \\
$1.0 \%$ wheat bran & $52.94 \pm 3.17$ \\
$0.5 \%$ oat xylan & $26.43 \pm 1.94$ \\
$1.0 \%$ oat xylan & $46.38 \pm 2.55$ \\
$0.5 \%$ corn cob & $12.66 \pm 3.29$ \\
$1.0 \%$ corn cob & $33.51 \pm 1.48$ \\
$1.0 \%$ starch & $1.95 \pm 0.46$ \\
$1.0 \%$ glucose & $2.82 \pm 0.98$ \\
$1.0 \%$ fructose & $0.83 \pm 0.12$ \\
$1.0 \%$ xylose & $20.32 \pm 2.41$ \\
$1.0 \%$ sobiol & $1.35 \pm 0.73$ \\
$1.0 \%$ maltose & $2.91 \pm 0.22$ \\
\hline
\end{tabular}

* Other media compositions/g/L: $\mathrm{KH}_{2} \mathrm{PO}_{4} 1.0, \mathrm{MgSO}_{4} \cdot 7 \mathrm{H}_{2} \mathrm{O} 1, \mathrm{CaCl}_{2} \cdot 2 \mathrm{H}_{2} \mathrm{O}$ 0.3 , and yeast extract 1.0.

xylan $18.3 \%$, and arabinan $10.1 \%$ ), proteins, fats, and vitamins and has been proved as an effective xylanase inducer. For example, comparing with corncob, cassava bran, corn straw, or sugar cane bagasse, Neosartorya spinosa strain P2D19 produced highest xylanase activity $(15.1 \mathrm{U} / \mathrm{mL})$ from wheat bran [20]. Xu et al. also reported that the highest xylanase activity achieved $1245 \mathrm{U} / \mathrm{mL}$ at a wheat bran concentration of $70.0 \mathrm{~g} \mathrm{~L}^{-1}$ by Pseudomonas sp. WLUN024 [21].

Xylose has also been proved as a xylanase inducer in some organisms such as Aureobasidium pullulans and Trichosporon cutaneum. In the present study, C. oxysporum GQ3 fermented xylose $(1.0 \%$, w/v) effectively to produce xylanase of $20.32 \mathrm{U} / \mathrm{mL}$. Other pure sugars such as glucose, fructose, and sobiol were not preferable for C. oxysporum with xylanase production of below $3.00 \mathrm{U} / \mathrm{mL}$, which might be due to their prevention of enzyme synthesis [22].

3.3. Effect of Nitrogen Source on Xylanase Production. As shown in Figure 3, organic nitrogen sources at a concentration of $1.0 \mathrm{~g} / \mathrm{L}$ benefited the xylanase production by $C$. oxysporum GQ3. Tryptone and yeast extract gave the high xylanase activities of $40.82 \mathrm{U} / \mathrm{mL}$ and $42.93 \mathrm{U} / \mathrm{mL}$, respectively. Similarly, Trichoderma harzianum PPDDN10 NFCCI2925 produced maximum xylanase activity of $2137.75 \mathrm{IU} / \mathrm{gds}$ with mycological peptone (MYP) [23]. In some cases, the inorganic nitrogen sources also benefited the xylanase production by fungi such as T. harzianum, S. commune, and T. lanuginosus [23]. In the present study, substitution of yeast extract in the basal media with inorganic nitrogen including $\mathrm{NH}_{4} \mathrm{Cl},\left(\mathrm{NH}_{4}\right)_{2} \mathrm{SO}_{4}$, ammonium citrate, and $\mathrm{NH}_{4} \mathrm{H}_{2} \mathrm{PO}_{4}$ improved xylanase production. The xylanase activity reached the highest level of $55.92 \mathrm{U} / \mathrm{mL}$ with $\mathrm{NH}_{4} \mathrm{Cl}$ as a nitrogen source $(P<0.05)$.

\subsection{Effect of Initial Medium $\mathrm{pH}$ and Temperature on Xylanase} Production. Generally, initial $\mathrm{pH}$ and fermentation temperature were regarded as the significant factors affecting cell growth and xylanase production by influencing nutrients 


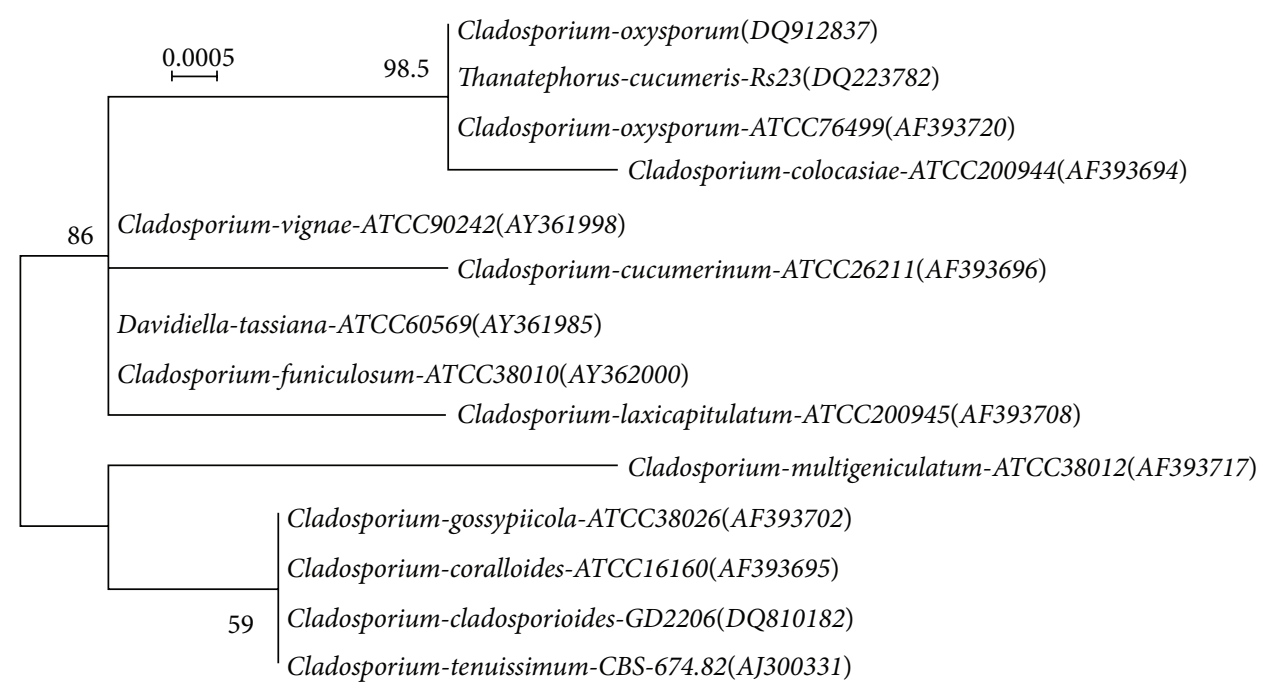

FIGURE 2: The phylogenetic dendrogram for Cladosporium oxysporum and related strains based on the ITS rDNA sequence. Numbers following the names of the strains are accessing numbers of published sequences.

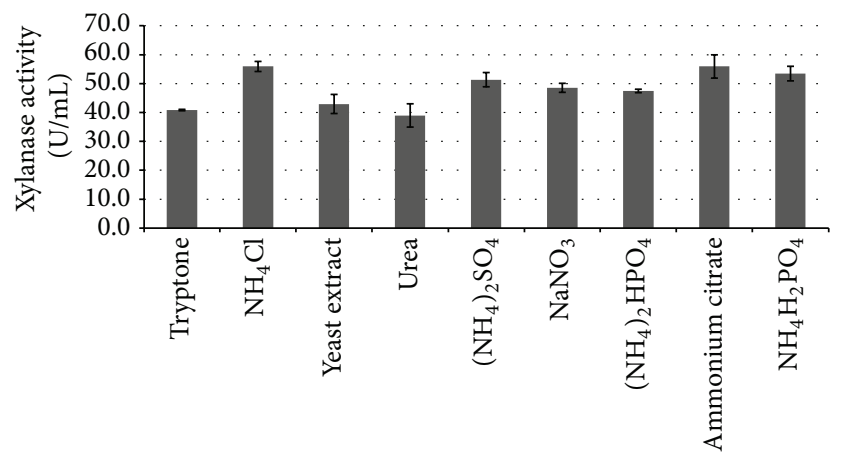

Nitrogen source

FIGURE 3: Effect of nitrogen source on xylanase production by C. oxysporum GQ-3 at $30^{\circ} \mathrm{C}$ under submerged fermentation for $5 \mathrm{~d}$ (other media compositions/g/L: wheat bran 10.0, $\mathrm{KH}_{2} \mathrm{PO}_{4} 1.0$, $\mathrm{MgSO}_{4} \cdot 7 \mathrm{H}_{2} \mathrm{O} 1.0$, and $\mathrm{CaCl}_{2} \cdot 2 \mathrm{H}_{2} \mathrm{O} 0.3$ ).

transport and corresponding enzymatic systems. Herein, $C$. oxysporum GQ-3 was cultivated in basal medium at $\mathrm{pH}$ values ranging from 3.0 to 9.0 to find the optimal initial $\mathrm{pH}$ for xylanase production. As shown in Figure 4(a), lower $\mathrm{pH}$ conditions (below $\mathrm{pH}$ 6.0) had the negative effect for $C$. oxysporum xylanase production. C. oxysporum had a higher xylanase production with the activity of over $44.2 \mathrm{U} / \mathrm{mL}$ at slightly acidic $\mathrm{pH}$ ( $\mathrm{pH} 6.0$ ), neutral $\mathrm{pH}$ ( $\mathrm{pH} 7.0$ ), and slight alkaline $\mathrm{pH}$ ( $\mathrm{pH} 7.0-8.0)$. Our previous study also found that Penicillium oxalicum $\mathrm{ZH}-30$ produced the highest xylanase activity of $14.91 \mathrm{U} / \mathrm{mL}$ at $\mathrm{pH} 7.72$ [16].

Figure 4 (b) presented the influence of temperature ranging from $25^{\circ} \mathrm{C}$ to $42^{\circ} \mathrm{C}$ on the xylanase production of $\mathrm{C}$. oxysporum with wheat bran concentration of $1.0 \%(\mathrm{w} / \mathrm{v})$. Temperature from $28^{\circ} \mathrm{C}$ to $30^{\circ} \mathrm{C}$ benefited C. oxysporum xylanase production with the highest activity of $52.84 \mathrm{U} / \mathrm{mL}$ at $30^{\circ} \mathrm{C}$. With temperature increase to $42^{\circ} \mathrm{C}$, xylanase production decreased significantly to $1.74 \mathrm{U} / \mathrm{mL}(P<0.05)$.
TABLE 2: Effect of metal ions on xylanase production by $C$. oxysporum GQ-3 at $30^{\circ} \mathrm{C}$ under submerged fermentation for $5 \mathrm{~d}$.

\begin{tabular}{lc}
\hline Metal ions $(\mathrm{mM})$ & Xylanase activity $(\mathrm{U} / \mathrm{mL})^{*}$ \\
\hline Control & $34.74 \pm 1.78$ \\
$\mathrm{~K}^{+}(1 \mathrm{mM})$ & $36.78 \pm 1.62$ \\
$\mathrm{Ca}^{2+}(1 \mathrm{mM})$ & $36.41 \pm 2.11$ \\
$\mathrm{Ca}^{2+}(5 \mathrm{mM})$ & $46.75 \pm 1.92$ \\
$\mathrm{Mg}^{2+}(1 \mathrm{mM})$ & $38.39 \pm 0.53$ \\
$\mathrm{Mg}^{2+}(5 \mathrm{mM})$ & $53.04 \pm 1.53$ \\
$\mathrm{Fe}^{2+}(1 \mathrm{mM})$ & $42.75 \pm 1.83$ \\
$\mathrm{Cu}^{2+}(1 \mathrm{mM})$ & $0.24 \pm 0.15$ \\
$\mathrm{Co}^{2+}(1 \mathrm{mM})$ & $33.81 \pm 0.74$ \\
$\mathrm{Mn}^{2+}(1 \mathrm{mM})$ & $36.32 \pm 0.92$ \\
\hline
\end{tabular}

${ }^{*}$ Media compositions/g/L: wheat bran 5.0 and yeast extract 1.0.

Nawel et al. also found that temperatures from $30^{\circ} \mathrm{C}$ to $37^{\circ} \mathrm{C}$ were suitable for cell growth and xylanase production of J. denitrificans BN-13 L [24]. Therefore, $30^{\circ} \mathrm{C}$ appeared to be the optimal temperature for xylanase production by $C$. oxysporum.

3.5. Effect of Metal Ions on Xylanase Production. Fungi require a unique combination of several unusual nutrient conditions, that is, hydrogen ions, dissolved oxygen certain trace metals, or phosphate for sufficient growth or xylanase production. Table 2 showed effect of 9 metal ions with the concentrations of $1.0 \mathrm{mM}$ or $5.0 \mathrm{mM}$ on C. oxysporum xylanase production. Compared with control result, supplementation of $\mathrm{Zn}^{2+}, \mathrm{Fe}^{2+}, \mathrm{Mg}^{2+}, \mathrm{Mn}^{2+}$, or $\mathrm{Ca}^{2+}$ was positive for xylanase production with activity of over $36.00 \mathrm{U} / \mathrm{mL} . \mathrm{Mg}^{2+}$ at the concentration of $5.0 \mathrm{mM}$ gave the maximum xylanase activity of $53.04 \mathrm{U} / \mathrm{mL}$. However, $\mathrm{Cu}^{2+}$ completely inhibited xylanase production with the activity of $0.24 \mathrm{U} / \mathrm{mL}(P<$ $0.05)$. A similar result also was found by Reis et al. with $17 \%$ 


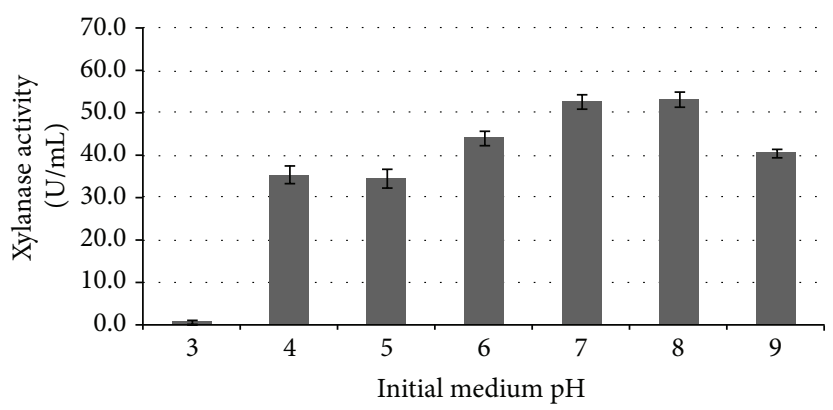

(a)

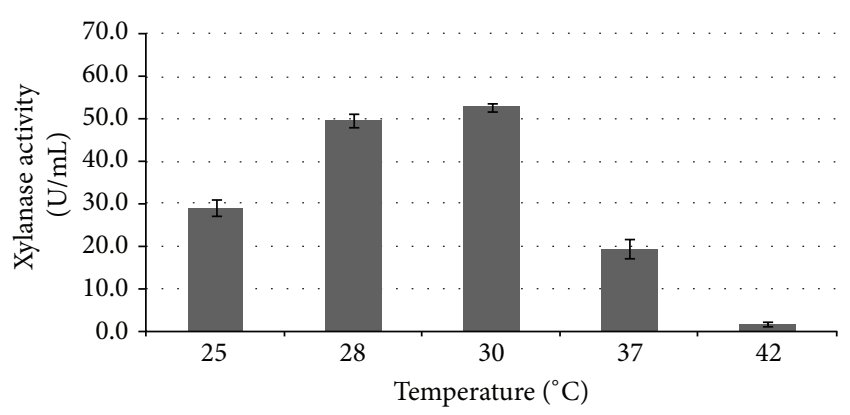

(b)

FIGURE 4: Effect of initial medium $\mathrm{pH}$ and temperature on xylanase production by Cladosporium oxysporum under submerged fermentation at $30^{\circ} \mathrm{C}$ (media compositions/g/L: wheat bran 10.0, $\mathrm{KH}_{2} \mathrm{PO}_{4} 1.0, \mathrm{MgSO}_{4} \cdot 7 \mathrm{H}_{2} \mathrm{O} 1.0, \mathrm{CaCl}_{2} \cdot 2 \mathrm{H}_{2} \mathrm{O} 0.3$, and $\mathrm{NH}_{4} \mathrm{Cl} 1.0$ ).

TABLE 3: Summary of xylanase purification from the fermentation broth of C. oxysporum.

\begin{tabular}{lccccc}
\hline Fraction & $\begin{array}{c}\text { Total protein } \\
(\mathrm{mg})\end{array}$ & $\begin{array}{c}\text { Total activity } \\
\text { (units) }\end{array}$ & $\begin{array}{c}\text { Specific activity } \\
\text { (U/mg protein) }\end{array}$ & $\begin{array}{c}\text { Yield } \\
(\%)\end{array}$ & $\begin{array}{c}\text { Purification } \\
\text { fold }\end{array}$ \\
\hline Culture filtrate & 1039.05 & 2737.83 & 2.63 & 100.00 & 1.00 \\
$\left(\mathrm{NH}_{4}\right)_{2} \mathrm{SO}_{4}$ precipitation & 97.56 & 987.28 & 10.12 & 36.06 & 3.61 \\
DEAE-Sepharose Fast Flow & 9.83 & 543.51 & 55.29 & 19.85 & 20.98 \\
\hline
\end{tabular}

of xylanase activity improvement $(30.50 \mathrm{U} / \mathrm{mL})$ after addition of $\mathrm{MgSO}_{4}$ and $\mathrm{CaCl}_{2}$ [25].

\subsection{Properties of the Partially Purified Xylanase}

3.6.1. Purification of Xylanase from the Fermentation Broth of C. oxysporum. Table 3 summarized the C. oxysporum xylanase yield and activity during 2 -step purification processes. Ammonium sulfate precipitation led to xylanase specific activity of $10.12 \mathrm{U} / \mathrm{mg}$ protein and increased purification fold to 3.61. During the DEAE-Sepharose Fast column chromatography, fraction eluted with PBS containing $0.3 \mathrm{~mol} / \mathrm{L}$ $\mathrm{NaCl}$ had the highest xylanase activity of $48.56 \mathrm{U} / \mathrm{mL}$ (elution profile not shown). The partially purified xylanase had the increased specific activity of $55.29 \mathrm{U} / \mathrm{mg}$ protein and purification fold of 20.98 .

3.7. Effect of $p H$ on Partially Purified Xylanase Activity. Catalytic $\mathrm{pH}$ markedly affects enzymes activity by dissociating bind of substrate and catalysis and even destroying their molecular structures. Figure 5 presented effect of $\mathrm{pH}$ on the xylanase activity and stability. As shown in Figure 5, alkaline condition (7.0-9.0) favored xylanase activity of $C$. oxysporum GQ3. Too high (over 9.0) or low (below 6.0) pH conditions significantly inhibited xylanase activity $(P<0.05)$. Hence, it could be concluded that $C$. oxysporum xylanase could tolerate alkaline conditions and is possibly classified as an alkaline xylanase. Figure 5 also demonstrated that partially purified C. oxysporum xylanase had the optimal activity with the relative value of $100 \%$ at $\mathrm{pH} 8.0$. Recently, alkali xylanases attract increasing interest for their applications in paper and feed industries, textile processes, enzymatic saccharification and waste treatments. For example, alkaline xylanase could directly treat the pulp with high $\mathrm{pH}$ and avoid the cost/time

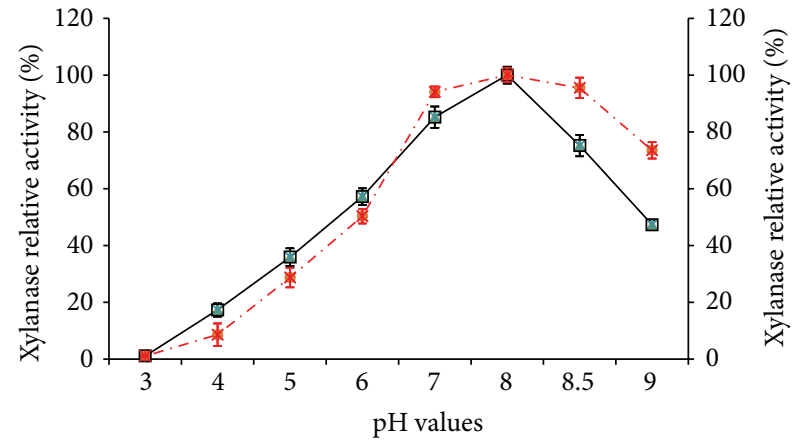

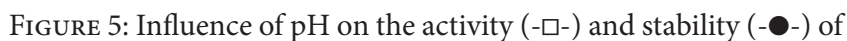
xylanase from C. oxysporum GQ3 (Media compositions/g/L: wheat bran 10.0, $\mathrm{KH}_{2} \mathrm{PO}_{4} 1.0, \mathrm{MgSO}_{4} \cdot 7 \mathrm{H}_{2} \mathrm{O} 1.0, \mathrm{CaCl}_{2} \cdot 2 \mathrm{H}_{2} \mathrm{O} 0.3$, and $\left.\mathrm{NH}_{4} \mathrm{Cl} 1.0\right)$.

consuming steps of $\mathrm{pH}$ readjustments. Similarly, Geobacillus thermodenitrificans also produced an alkali xylanase with the maximum activity at $\mathrm{pH} 7.5$ and $70^{\circ} \mathrm{C}$ [26].

3.8. Effect of Temperature on Partially Purified Xylanase Activity and Thermostability. From Figure 6(a), C. oxysporum xylanase activity increased from $32.64 \mathrm{U} / \mathrm{mL}$ to $56.90 \mathrm{U} / \mathrm{mL}$ with increase of temperature from $20^{\circ} \mathrm{C}$ to $50^{\circ} \mathrm{C}$ and then decreased to $37.64 \mathrm{U} / \mathrm{mL}$ at $50^{\circ} \mathrm{C}$ and even $14.44 \mathrm{U} / \mathrm{mL}$ at $70^{\circ} \mathrm{C}$. Hence, the optimum catalytic temperature of C. oxysporum xylanase was regarded as $50^{\circ} \mathrm{C}$.

C. oxysporum xylanase had the stable activity at below $50^{\circ} \mathrm{C}$ (Figure 6(b)) and approximately $44.30 \%$ of its activity remained at $55^{\circ} \mathrm{C}$ for $3 \mathrm{~h}$. Over $95 \%$ of activity was lost after 2 -h treatment at over $60^{\circ} \mathrm{C}$. These results indicated that $40-$ $50^{\circ} \mathrm{C}$ was the suitable temperature for future application of $C$. oxysporum xylanase. 


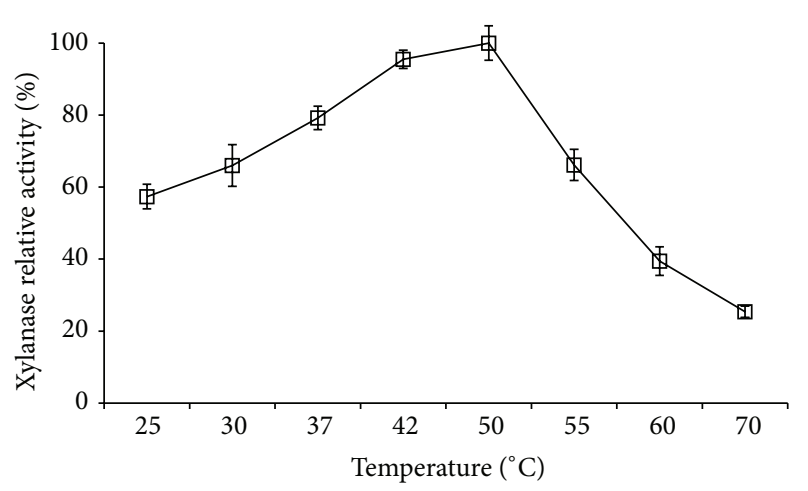

(a)

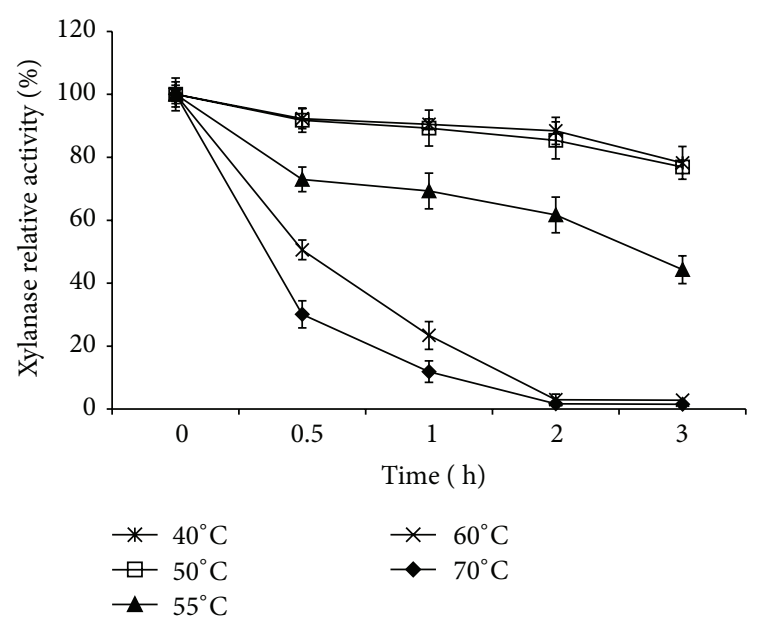

(b)

FIGURE 6: Influence of temperature on the activity of xylanase and its thermostability from Cladosporium oxysporum GQ3.

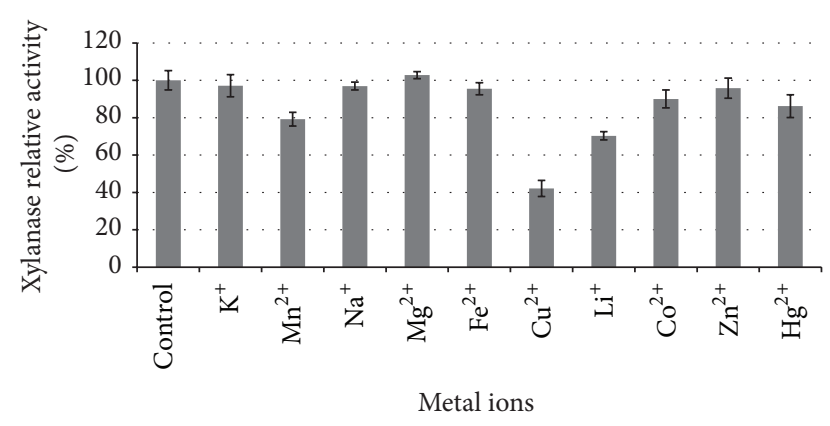

FIGURE 7: Influence of metal ions on the activity of xylanase from Cladosporium oxysporum GQ3.

3.9. Effect of Metal Ions on Partially Purified Xylanase Activity. As shown in Figure 7, most of the metal ions $(1.0 \mathrm{mM})$ had a slight inhibition of about $5.0 \%$ on the partially purified xylanase activity while $\mathrm{Cu}^{2+}$ had the highest inhibition ratio of $57.9 \% . \mathrm{Mg}^{2+}$ slightly enhanced partially purified xylanase activity by $2.8 \%$, indicating its possible role as a metal ion cofactor. Previously references have revealed that xylanases activity depended on their producers and metal ion types. For example, $\mathrm{Na}^{+}$and $\mathrm{Mn}^{2+}$ strongly inhibited $33.2 \%$ and $80.5 \%$ of Alternaria mali xylanase activity while $\mathrm{K}^{+}, \mathrm{Li}^{+}, \mathrm{Fe}^{2+}, \mathrm{Cu}^{2+}$, and $\mathrm{Zn}^{2+}$ showed no significant effect [16]. $\mathrm{Mn}^{2+}$ significantly inhibited Streptomyces sp. xylanase [27], while $\mathrm{Hg}^{2+}$ strongly inhibited $66.0 \%$ and $\mathrm{Ca}^{2+}$ stimulated $51.3 \%$ of C. algeriensis xylanase [28].

3.10. Protease Resistance of Partially Purified Xylanase Activity. The partially purified xylanase from C. oxysporum GQ3 showed the resistance to neutral and alkaline proteases when incubated with pepsin, trypsin, collagenase, and proteinase $\mathrm{K}$ at $37^{\circ} \mathrm{C}$ for $3 \mathrm{~h}$. The enzyme retained unchanged activity with collagenase treatment while residual activity was $95.8 \%$ and 91.3\% of the maximum xylanase activity after the incubation with proteinase $\mathrm{K}$ and trypsin, respectively. Interestingly, xylanase produced by Streptomyces sp. TN119 GH 11 also exhibited significant re sistance to protease digestion and even increased its activity by $5.8 \%, 9.4 \%, 21.6 \%$, and $129.0 \%$ after treatments of trypsin, collagenase, $\alpha$-chymotrypsin, and proteinase K, respectively [29].

\section{Conclusions}

In conclusion, the isolated fungus C. oxysporum GQ-3 was proved as an efficient xylanase producer with the agroindustrial residue wheat bran as substrate. The C. oxysporum partially purified xylanase activity has the optimal catalytic $\mathrm{pH}$ and temperature of 8.0 and $50^{\circ} \mathrm{C}$, respectively. It showed the $\mathrm{pH}$ and thermostable activities while influenced by metal ions. Our study will provide a reference for better understanding of xylanase from C. oxysporum and further improving the strain for large scale production and industrial application such as textile processes or paper and feed industries.

\section{Competing Interests}

The authors declare that they have no competing interests.

\section{Acknowledgments}

This work was financially supported by funds from the State Grid Science and Technology Program (no. SGECS 562014) and China Ministry of Science and Technology (no. 2014DFG32550), International Foundation for Science (no. F/4930-2F), and Priority Academic Program Development of Jiangsu Higher Education Institutions.

\section{References}

[1] R. Deutschmann and R. F. H. Dekker, "From plant biomass to bio-based chemicals: latest developments in xylan research," Biotechnology Advances, vol. 30, no. 6, pp. 1627-1640, 2012.

[2] V. Menon and M. Rao, "Trends in bioconversion of lignocellulose: biofuels, platform chemicals \& biorefinery concept," 
Progress in Energy and Combustion Science, vol. 38, no. 4, pp. 522-550, 2012.

[3] J. S. Van Dyk and B. I. Pletschke, "A review of lignocellulose bioconversion using enzymatic hydrolysis and synergistic cooperation between enzymes-factors affecting enzymes, conversion and synergy," Biotechnology Advances, vol. 30, no. 6, pp. 14581480, 2012.

[4] N. Kulkarni, A. Shendye, and M. Rao, "Molecular and biotechnological aspects of xylanases," FEMS Microbiology Reviews, vol. 23, no. 4, pp. 411-456, 1999.

[5] V. Juturu and J. C. Wu, "Microbial exo-xylanases: a mini review," Applied Biochemistry and Biotechnology, vol. 174, no. 1, pp. 8192, 2014.

[6] P. Chutani and K. K. Sharma, "Biochemical evaluation of xylanases from various filamentous fungi and their application for the deinking of ozone treated newspaper pulp," Carbohydrate Polymers, vol. 127, pp. 54-63, 2015.

[7] B. V. McCleary, V. A. McKie, A. Draga, E. Rooney, D. Mangan, and J. Larkin, "Hydrolysis of wheat flour arabinoxylan, aciddebranched wheat flour arabinoxylan and arabino-xylo-oligosaccharides by $\beta$-xylanase, $\alpha$-l-arabinofuranosidase and $\beta$ xylosidase," Carbohydrate Research, vol. 407, pp. 79-96, 2015.

[8] N. Liu, Y. J. Ru, D. F. Tang, T. S. Xu, and G. G. Partridge, "Effects of corn distillers dried grains with solubles and xylanase on growth performance and digestibility of diet components in broilers," Animal Feed Science and Technology, vol. 163, no. 24, pp. 260-266, 2011.

[9] A. Pal and F. Khanum, "Efficacy of xylanase purified from Aspergillus niger DFR-5 alone and in combination with pectinase and cellulase to improve yield and clarity of pineapple juice," Journal of Food Science and Technology, vol. 48, no. 5, pp. 560-568, 2011.

[10] X. L. Xue, R. Wang, T. Tu et al., “The N-terminal GH10 domain of a multimodular protein from Caldicellulosiruptor bescii is a versatile xylanase/ $\beta$-glucanase that can degrade crystalline cellulose," Applied and Environmental Microbiology, vol. 81, no. 11, pp. 3823-3833, 2015.

[11] D. Sutay Kocabaş, S. Güder, and N. Özben, "Purification strategies and properties of a low-molecular weight xylanase and its application in agricultural waste biomass hydrolysis," Journal of Molecular Catalysis B: Enzymatic, vol. 115, pp. 66-75, 2015.

[12] W. Wang, Z. Wang, B. Cheng et al., "High secretory production of an alkaliphilic actinomycete xylanase and functional roles of some important residues," World Journal of Microbiology and Biotechnology, vol. 30, no. 7, pp. 2053-2062, 2014.

[13] L. M. Zhao, J. Geng, Y. Q. Guo et al., "Expression of the Thermobifida fusca xylanase Xyn11A in Pichia pastoris and its characterization," BMC Biotechnology, vol. 15, article 18, 2015.

[14] F. Cui and L. Zhao, "Optimization of xylanase production from Penicillium sp.WX-Z1 by a two-step statistical strategy: PlackettBurman and Box-Behnken experimental design," International Journal of Molecular Sciences, vol. 13, no. 8, pp. 10630-10646, 2012.

[15] F. Cui, Y. Li, Z. Liu et al., "Optimization of fermentation conditions for production of xylanase by a newly isolated strain, Penicillium thiersii ZH-19," World Journal of Microbiology and Biotechnology, vol. 25, no. 4, pp. 721-725, 2009.

[16] Y. Li, F. J. Cui, Z. Q. Liu, Y. Y. Xu, and H. Zhao, "Improvement of xylanase production by Penicillium oxalicum $\mathrm{ZH}-30$ using response surface methodology," Enzyme and Microbial Technology, vol. 40, no. 5, pp. 1381-1388, 2007.
[17] G. L. Miller, "Use of dinitrosalicylic acid reagent for determination of reducing sugar," Analytical Chemistry, vol. 31, no. 3, pp. 426-428, 1959.

[18] M. J. Samways and N. M. Grech, "Assessment of the fungus Cladosporium oxysporum (Berk. and Curt.) as a potential biocontrol agent against certain homoptera," Agriculture, Ecosystems and Environment, vol. 15, no. 4, pp. 231-239, 1986.

[19] K. Gokul Raj, R. Manikandan, C. Arulvasu, and M. Pandi, "Antiproliferative effect of fungal taxol extracted from Cladosporium oxysporum against human pathogenic bacteria and human colon cancer cell line HCT 15," Spectrochimica Acta Part A: Molecular and Biomolecular Spectroscopy, vol. 138, no. 5, pp. 667-674, 2015.

[20] H. F. Alves-Prado, F. C. Pavezzi, R. S. R. Leite, V. M. de Oliveira, L. D. Sette, and R. Dasilva, "Screening and production study of microbial xylanase producers from brazilian cerrado," Applied Biochemistry and Biotechnology, vol. 161, no. 1-8, pp. 333-346, 2010.

[21] Z. Xu, Y. Bai, X. Xu, J. Shi, and W. Tao, "Production of alkalitolerant cellulase-free xylanase by Pseudomonas sp. WLUN024 with wheat bran as the main substrate," World Journal of Microbiology and Biotechnology, vol. 21, no. 4, pp. 575-581, 2005.

[22] I. Seyis and N. Aksoz, "Effect of carbon and nitrogen sources on xylanase production by Trichoderma harzianum 1073 D3," International Biodeterioration \& Biodegradation, vol. 55, no. 2, pp. 115-119, 2005.

[23] P. Pathak, N. K. Bhardwaj, and A. K. Singh, "Production of crude cellulase and xylanase from Trichoderma harzianum PPDDN10 NFCCI-2925 and its application in photocopier waste paper recycling," Applied Biochemistry and Biotechnology, vol. 172, no. 8, pp. 3776-3797, 2014.

[24] B. Nawel, B. Said, C. Estelle, H. Hakim, and F. Duchiron, "Production and partial characterization of xylanase produced by Jonesia denitrificans isolated in Algerian soil," Process Biochemistry, vol. 46, no. 2, pp. 519-525, 2011.

[25] L. dos Reis, C. E. T. Ritter, R. C. Fontana, M. Camassola, and A. J. P. Dillon, "Statistical optimization of mineral salt and urea concentration for cellulase and xylanase production by Penicillium echinulatum in submerged fermentation," Brazilian Journal of Chemical Engineering, vol. 32, no. 1, pp. 13-22, 2015.

[26] L. Marcolongo, F. La Cara, A. Morana et al., "Properties of an alkali-thermo stable xylanase from Geobacillus thermodenitrificans A333 and applicability in xylooligosaccharides generation," World Journal of Microbiology and Biotechnology, vol. 31, no. 4, pp. 633-648, 2015.

[27] R. P. Nascimento, R. R. R. Coelho, S. Marques et al., "Production and partial characterisation of xylanase from Streptomyces sp. strain AMT-3 isolated from Brazilian cerrado soil," Enzyme and Microbial Technology, vol. 31, no. 4, pp. 549-555, 2002.

[28] K. Bouacem, A. Bouanane-Darenfed, N. Boucherba et al., "Partial characterization of xylanase produced by Caldicoprobacter algeriensis, a new thermophilic anaerobic bacterium isolated from an algerian hot spring," Applied Biochemistry and Biotechnology, vol. 174, no. 5, pp. 1969-1981, 2014.

[29] J. P. Zhou, P. J. Shi, R. Zhang et al., "Symbiotic Streptomyces sp. TN119 GH 11 xylanase: a new pH-stable, protease- and SDSresistant xylanase," Journal of Industrial Microbiology \& Biotechnology, vol. 38, no. 4, pp. 523-530, 2011. 

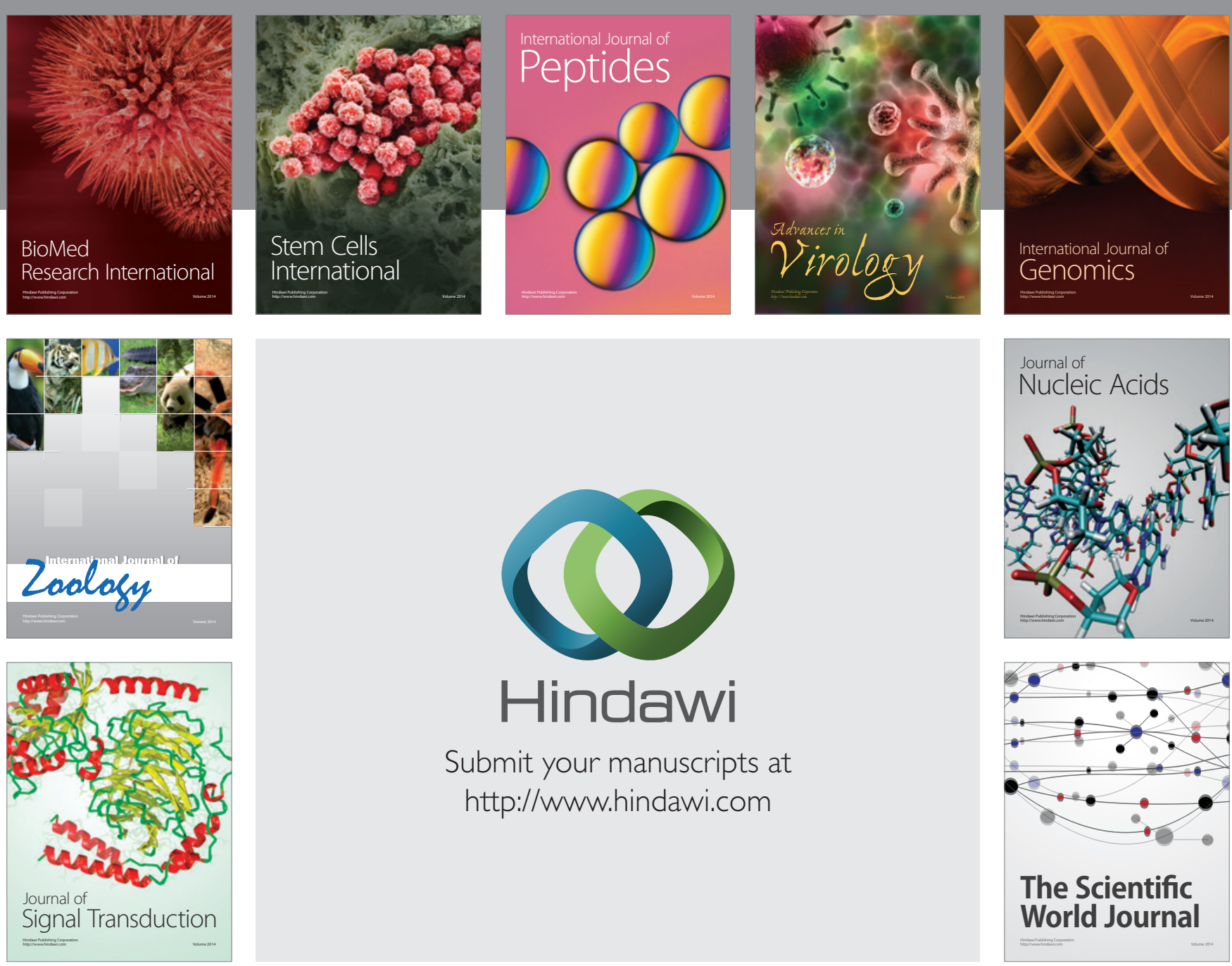

Submit your manuscripts at

http://www.hindawi.com
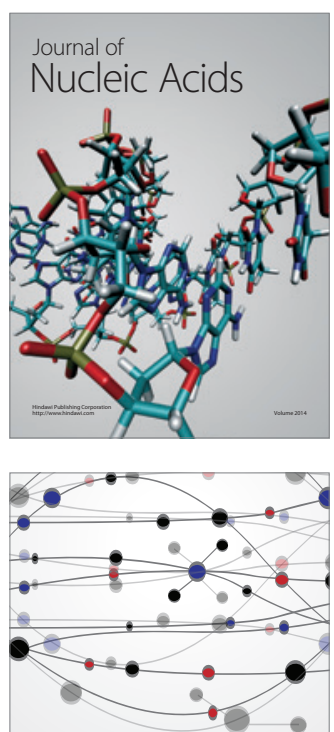

The Scientific World Journal
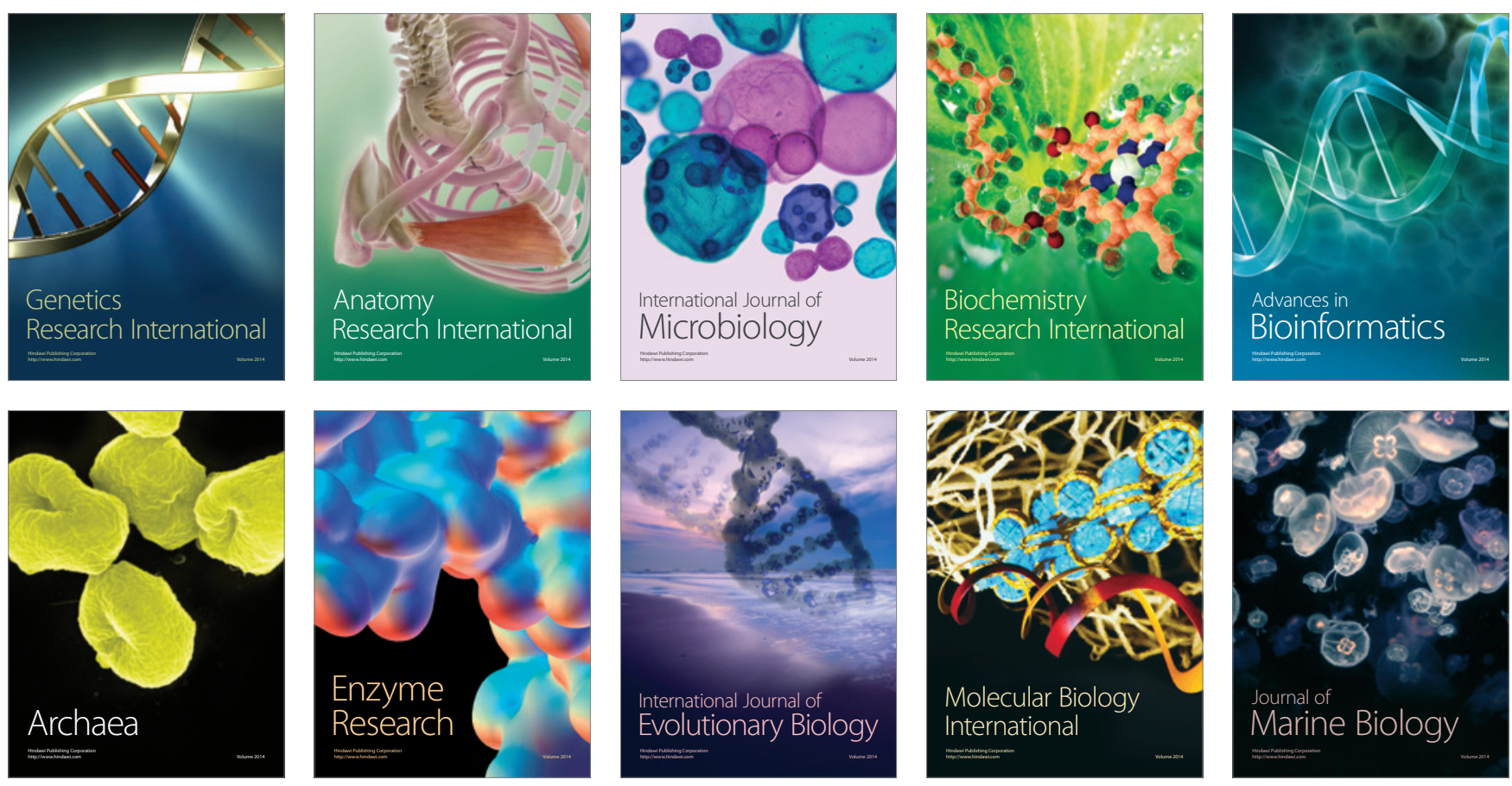